\title{
Looking beyond parks: the conservation value of unprotected areas for hornbills in Arunachal Pradesh, Eastern Himalaya
}

\author{
Rohit Nanimadekar, Charudutt Mishra, Kavita Isvaran \\ M. D. Madhusudan and Aparajtita Datta
}

\begin{abstract}
The loss of tropical forests and associated biodiversity is a global concern. Conservation efforts in tropical countries such as India have mostly focused on state-administered protected areas despite the existence of vast tracts of forest outside these areas. We studied hornbills (Bucerotidae), an ecologically important vertebrate group and a flagship for tropical forest conservation, to assess the importance of forests outside protected areas in Arunachal Pradesh, north-east India. We conducted a state-wide survey to record encounters with hornbills in seven protected areas, six state-managed reserved forests and six community-managed unclassed forests. We estimated the density of hornbills in one protected area, four reserved forests and two unclassed forests in eastern Arunachal Pradesh. The state-wide survey showed that the mean rate of encounter of rufous-necked hornbills Aceros nipalensis was four times higher in protected areas than in reserved forests and 22 times higher in protected areas than in unclassed forests. The mean rate of encounter of wreathed hornbills Rhyticeros undulatus was twice as high in protected areas as in reserved forests and eight times higher in protected areas than in unclassed forests. The densities of rufous-necked hornbill were higher inside protected areas, whereas the densities of great hornbill Buceros bicornis and wreathed hornbill were similar inside and outside protected areas. Key informant surveys revealed possible extirpation of some hornbill species at sites in two protected areas and three unclassed forests. These results highlight a paradoxical situation where individual populations of hornbills are being lost even in some legally protected habitat, whereas they continue to persist over most of the landscape. Better protection within protected areas and creative communitybased conservation efforts elsewhere are necessary to maintain hornbill populations in this biodiversity-rich region.
\end{abstract}

Rohit NANIWADEKAR* (Corresponding author), CharudutT Mishra $\dagger$, M. D. Madhusudan and AparajtTa DatTa Nature Conservation Foundation, 3076/5, IV Cross, Gokulam Park, Mysore-570002, Karnataka, India. E-mail rohit@ncf-india.org

KAVITA Isvaran Centre for Ecological Sciences, Indian Institute of Science, Bangalore, Karnataka, India

*Also at: Manipal University, Manipal 576104, Karnataka, India $\dagger$ Also at: Snow Leopard Trust, Seattle, Washington, USA

Received 12 July 2012. Revision requested 27 January 2013. Accepted 15 May 2013. First published online 13 March 2014.
Keywords Aceros nipalensis, Buceros bicornis, communityowned forest, hornbill abundance, Namdapha National Park, protected area, Rhyticeros undulatus

This paper contains supplementary material that can be found online at http://journals.cambridge.org

\section{Introduction}

Tropical forests harbour 50\% of the known global 1 biodiversity (Dirzo \& Raven, 2003) but these forests are under threat from logging, agriculture and other landuse changes (Curran et al., 2004; Gaveau et al., 2007). The rate of tropical forest loss in Asia is high, estimated at 2.9\% during 2000-2005 (Achard et al., 2002; Hansen et al., 2008). Although protected areas are intended to reduce the rates of forest loss (Sanchez-Azofeifa et al., 2002; NaughtonTreves et al., 2005) the current network of protected areas is inadequate for conserving tropical biodiversity (Rodrigues et al., 2004). Therefore there is a need for improved biodiversity conservation in areas outside protected areas (Daily, 2001). Forested areas outside protected areas are important as they increase the effective habitat size (Pimm et al., 1988) and act as buffers to reduce anthropogenic pressures on protected areas (Brashares et al., 2001; Laurance et al., 2002).

The state of Arunachal Pradesh in north-east India is part of the Eastern Himalaya biodiversity hotspot. More than $60 \%$ of its land area is under forest cover. However, $81.5 \%$ of this forested area lies outside the protected area network (FSI, 2009) and potentially harbours important and threatened wildlife (Mishra et al., 2006; Aiyadurai et al., 2010). Hornbills are a key ecological group in Asian tropical forests. They are the largest volant frugivores and range over large areas (Keartumsom et al., 2011) in search of patchily distributed fruit resources. They play an important functional role as seed dispersers (Datta, 2001; Kitamura, 2011). Of the 31 species of Asian hornbills, nine are found in India, and five of these occur in Arunachal Pradesh: rufous-necked hornbill Aceros nipalensis, brown hornbill Anorrhinus austeni, great hornbill Buceros bicornis, wreathed hornbill Rhyticeros undulatus and oriental pied hornbill Anthracoceros albirostris. The rufous-necked hornbill is categorized as Vulnerable and the great and 


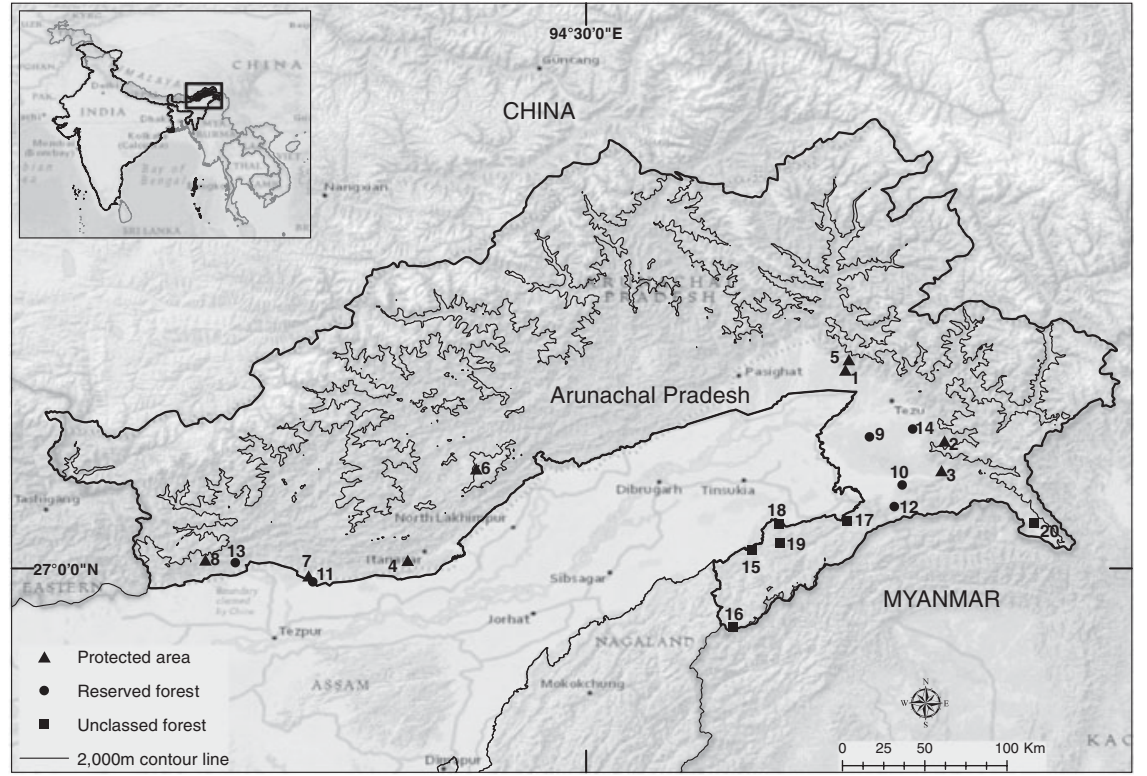

FIG. 1 Locations of sampling sites across the state of Arunachal Pradesh, northeast India. The numbers correspond to those in the state-wide survey section of Table 1. The rectangle on the inset indicates the location of the main map in India. brown hornbills as Near Threatened on the IUCN Red List of Threatened Species (IUCN, 2011).

In Arunachal Pradesh, as in other parts of South-east Asia, hornbills are hunted for their meat, body parts (casque and tail feathers) and fat (Bennett et al., 1997; Datta, 2002; Kinnaird \& O'Brien, 2007). Given the extensive hornbill habitat that lies outside protected areas, a considerable proportion of the state's hornbill population probably occurs outside these areas. We surveyed 20 sites across the state to assess the status of hornbills within and outside protected areas. We carried out field surveys and key informant interviews, focusing primarily on landscapes outside protected areas, including those under the de facto ownership of local communities as well as those managed by the State Forest Department. We included some sites within protected areas for comparison. We complemented these landscape-level assessments at multiple sites across Arunachal Pradesh with intensive efforts to estimate hornbill density both within and outside protected areas in the eastern part of the state.

\section{Study area}

The survey was carried out across the state of Arunachal Pradesh (Fig. 1), which has a human population density of 17 persons $\mathrm{km}^{-2}$ (country mean $382 \mathrm{~km}^{-2}$ ) and a decadal population growth rate of $25.92 \%$ (country mean $17.5 \%$; Indian Census, 2011). The protected areas in the state include two tiger reserves, eight wildlife sanctuaries and one national park, which account for $18.5 \%$ of the state's forested area. National parks are 'inviolate' areas, where human residence and activities such as hunting and logging are prohibited. In wildlife sanctuaries subsistence activities such as collection of wood for fuel by local communities and cattle grazing are permitted. The forested areas outside protected areas can be classified as reserved forests or unclassed forests. Logging may be carried out in reserved forests under the working plan prescriptions made for different divisions of the State Forest Department. Unclassed forests, although recorded as forests by the State Forest Department, are under the de facto control of local tribal communities. Logging is carried out in unclassed forests with the consent of the local communities, using the working schemes of the local Forest Divisions. Indian wildlife is categorized under six schedules in the Wildlife (Protection) Act of India, 1972. Hunting of wild animals in Schedules I-IV is illegal. All five hornbill species are categorized under Schedule I of the Act.

We sampled eight sites in seven protected areas and six sites each in reserved forests and unclassed forests (Fig. 1; Table 1). Our aim was to represent adequately the variability in rates of encounters with hornbills across the three regimes and therefore we placed greater emphasis on surveying several independent sites than on intensive sampling at any one site. We sampled across the entire elevation gradient occupied by hornbills in Arunachal Pradesh (150-2,300 m; Table 1).

To obtain more precise information on hornbill abundance in the different administrative regimes we sampled intensively at one site in a protected area (Namdapha National Park), four sites in ecologically comparable reserved forests and two sites in unclassed forests. Intensive sampling resulted in a higher number of detections and allowed us to account for differential detectability between sites, which we were unable to do in the state-wide surveys. 
TABLE 1 Details of sites sampled for hornbill species in Arunachal Pradesh, north-east India (Fig. 1) during state-wide and intensive surveys, with the site name, trail lengths, name of protected area, reserved forest or unclassed forest, elevational range of sampling, total sampling effort, and sampling period.

\begin{tabular}{|c|c|c|c|c|c|}
\hline No. & Site (trail lengths, km) & $\begin{array}{l}\text { Protected area/reserved } \\
\text { forest/unclassed forest }\end{array}$ & Elevation $(\mathrm{m})$ & $\begin{array}{l}\text { Total effort } \\
(\mathrm{km})\end{array}$ & Sampling period \\
\hline \multicolumn{6}{|c|}{ State-wide surveys } \\
\hline 1 & Abango (5) & Mehao WS & $400-500$ & 5 & Jan. 2008 \\
\hline 2 & Glao Lake $(14,3,14)$ & Kamlang WS & $400-1,300$ & 31 & Feb. 2008 \\
\hline 3 & Hornbill Plateau $(8,3,3,8)$ & Namdapha TR & $500-600$ & 22 & Mar. 2008 \\
\hline 4 & Jotte $(5,7)$ & Itanagar WS & $200-300$ & 12 & Apr. 2008 \\
\hline 5 & Mehao Lake $(7,2,7)$ & Mehao WS & $400-1,750$ & 16 & Feb. 2008 \\
\hline 6 & Monipoliyang-Pange-Tale $(6,9,9,6)$ & Tale WS & $1,500-2,300$ & 30 & Mar. 2008 \\
\hline 7 & Seijusa (2) & Pakke TR & $150-300$ & 6 & Apr. 2008 \\
\hline 8 & Sessni $(2,2.5,2)$ & Eaglenest WS & $1,200-1,400$ & 6.5 & Apr. 2008 \\
\hline 9 & Madhuban (5) & Tengapani RF & $200-250$ & 5 & Mar. 2008 \\
\hline 10 & $\operatorname{Miao}(6)$ & Miao RF & $350-800$ & 12 & Feb. 2008 \\
\hline 11 & Monai $(3.5,2.1,3)$ & Papum RF & $150-250$ & 8.6 & Apr. 2008 \\
\hline 12 & Rima (2) & Rima RF & $400-750$ & 34 & Nov. 2008-Apr. 2009 \\
\hline 13 & Tipi $(5,2,1.7)$ & Doimara RF & $200-400$ & 17.4 & Apr. 2008 \\
\hline 14 & Turung (5) & Turung RF & $230-250$ & 10 & Mar. 2008 \\
\hline 15 & Hukanjuri (2.5) & UF, Deomali FD & $170-250$ & 5 & Feb. 2008 \\
\hline 16 & Konnu (1) & Kanubari UF, Deomali FD & $1,050-1,150$ & 1 & Jan. 2008 \\
\hline 17 & Manmao (4) & Manmao UF, Jairampur FD & $700-850$ & 8 & Feb. 2008 \\
\hline 18 & Mopaya (4) & UF, Deomali FD & $160-520$ & 8 & Feb. 2008 \\
\hline 19 & Soha (7) & UF, Deomali FD & $550-1,150$ & 7 & Feb. 2008 \\
\hline 20 & Yakhulo (1.3) & Vijaynagar UF, Jairampur FD & $1,200-1,400$ & 20.8 & Jan.-Apr. 2009 \\
\hline \multicolumn{6}{|c|}{ Intensive surveys } \\
\hline 1 & Bulbulia (2) & Namdapha TR & 550 & 48 & Jan.-Apr. 2009 \\
\hline 2 & Hornbill (2) & Namdapha TR & 500 & 46 & Jan.-Apr. 2009 \\
\hline 3 & Rajajheel (2) & Namdapha TR & 850 & 50 & Jan.-Apr. 2009 \\
\hline 4 & Ranijheel (1.7) & Namdapha TR & 850 & 45.9 & Jan.-Apr. 2009 \\
\hline 5 & Madhuban 1 (1.5) & Tengapani RF & $200-250$ & 33 & Jan.-Apr. 2009 \\
\hline 6 & Madhuban 2 (1.5) & Tengapani RF & $200-250$ & 31.5 & Jan.-Apr. 2009 \\
\hline 7 & Madhuban 3 (1.5) & Tengapani RF & $200-250$ & 34.5 & Jan.-Apr. 2009 \\
\hline 8 & Madhuban 4 (1.5) & Tengapani RF & $200-250$ & 30 & Jan.-Apr. 2009 \\
\hline 9 & Miao (2) & Miao RF & $350-700$ & 42 & Nov. 2008-Apr. 2009 \\
\hline 10 & Rima (2) & Rima RF & $400-750$ & 34 & Nov. 2008-Apr. 2009 \\
\hline 11 & Turung (3) & Turung RF & $230-250$ & 27 & Jan.-Apr. 2009 \\
\hline 12 & Manmao (1.7) & Manmao UF, Jairampur FD & $700-850$ & 25.5 & Nov. 2008-Apr. 2009 \\
\hline 13 & Yakhulo (1.3) & Vijaynagar UF, Jairampur FD & $1,200-1,400$ & 20.8 & Jan.-Apr. 2009 \\
\hline
\end{tabular}

${ }^{\star}$ WS, Wildlife Sanctuary; TR, Tiger Reserve; RF, Reserved Forest; UF, Unclassed Forest; FD, Forest Division 


\section{Methods}

\section{State-wide surveys}

We sampled hornbill abundance along existing trails at each site during 06.00-13.00 from January to April 2008. Our sampling was carried out mainly during the nonbreeding season, which in Arunachal Pradesh is between the end of March and early August (Datta \& Rawat, 2004). The total effort across all 20 sites was $265.3 \mathrm{~km}$ (mean $13.3 \mathrm{~km}$ per site). The mean length of trails sampled was $4.4 \mathrm{~km}$ (range 1-14 km; Table 1). On sighting a hornbill flock we recorded the species and the number of individuals. Species were also identified by their calls. We used visual and aural detections to calculate hornbill flock encounter rates as the number of flocks (sightings or calls) per $\mathrm{km}$ of sampling effort.

Our state-wide surveys were not adequate to confirm the absence of hornbill species at a site. Therefore we conducted semi-structured key informant interviews $(n=78)$, with at least two hunters at each site, to ascertain the presence of species that were not recorded during our walks. The interviews were conducted at villages close to the sampling site. We used the point-centred quarter method (Cottam \& Curtis, 1956) at 15 sites and 10-m-radius circular plots at five sites to estimate tree density (girth at breast height $\geq 30 \mathrm{~cm}$ ) and total basal area per ha. Every $100 \mathrm{~m}$ along the trail we measured the distance to the nearest tree (girth at breast height $\geq 30 \mathrm{~cm}$ ) and its girth, in each of the quarters around the observer. We sampled at 20 such points along the length of the trail except at one site (Konnu), where the distance interval was reduced to $75 \mathrm{~m}$ as the trail was short. The circular plots were spaced at $100 \mathrm{~m}$ intervals. The number of plots along a trail was $15-35$, depending on the length of the trail.

\section{Intensive surveys in eastern Arunachal Pradesh}

We carried out temporally replicated line-transect surveys along four trails in a protected area (Namdapha Tiger Reserve), seven trails at four reserved forest sites (Tengapani, Turung, Miao and Rima) and one trail at each of two unclassed forest sites (Manmao and Vijaynagar) in eastern Arunachal Pradesh from November 2008 to April 2009 (Table 1). Trail length was $1.3-3.0 \mathrm{~km}$ and the total effort along each trail was $20.8-50 \mathrm{~km}$, yielding an overall sampling effort of $486.2 \mathrm{~km}$. One or two observers walked each trail in the morning (05.00-10.00) and/or in the evening (13.00-17.00). We recorded species identity, number of individuals and the perpendicular distance to the centre of the flock, following standard line-transect protocol (Buckland et al., 2003). The mean walking speed was $1.6 \mathrm{~km}$ per hour. Distances were measured using a rangefinder.

\section{Analysis of state-wide survey data}

Particular hornbill species are known to occur within a certain range of elevation, therefore we needed to control for the confounding effects of elevation on natural species absence while investigating species responses within and outside protected areas. Based on existing knowledge (Katti et al., 1992; Datta et al., 1998; Kemp, 2001) and previous experience we used data only from sites within the known elevational distribution of each species. The great hornbill and brown hornbill usually occur from the plains and lowelevation forests up to $1,000 \mathrm{~m}$, although the great hornbill is known to occur up to $2,000 \mathrm{~m}$; the rufous-necked hornbill occurs at 150-2,200 $\mathrm{m}$, but usually within 600-1,800 m; and the wreathed hornbill occurs mainly from foothills to $2,560 \mathrm{~m}$. We omitted data from two protected area sites (Sessni and Monipoliyang-Pange-Tale) and two unclassed forest sites (Yakhulo and Konnu) that were higher than the known preferred elevation range of great hornbill. For the rufous-necked hornbill we omitted five low-elevation sites, including three in protected areas (Jotte, Seijusa and Abango) and two in reserved forests (Tipi and Monai). For the wreathed hornbill, we included data from all sites as this species occurs across the entire sampled elevation gradient (150-2,500 m).

We used generalized linear models on the count data for hornbill flock detections for comparison across the three site categories (protected area, reserved forest and unclassed forest). The natural logarithm of effort was used as an offset to control for differences in sampling effort between the sites. As generalized linear models with Poisson errors indicated over-dispersion in the data we used a negative binomial model with a log link. We carried out this analysis separately for great, rufous-necked and wreathed hornbills. We did not carry out analysis for oriental pied hornbills, because of a paucity of detections, or brown hornbills, which are geographically restricted to eastern Arunachal Pradesh. Statistical inference was based on model selection using an information-theoretic approach (Burnham \& Anderson, 2002). For each of the three species we specified and fitted two models (a basic model with only intercept and a second with an administrative category as a predictor). We used the corrected Akaike's information criterion $\left(\mathrm{AIC}_{\mathrm{c}}\right)$ to evaluate the relative fit between two candidate models. $\mathrm{AIC}_{\mathrm{c}}$ is recommended for small sample sizes where the ratio of sample size to the number of parameters is $<40$ (Burnham \& Anderson, 2002). The model with the smallest $\mathrm{AIC}_{\mathrm{c}}$ value is the best estimate of the unknown 'true' model based on our data. The administrative regimes were indicators of anthropogenic pressures on each site. To assess independently the effects of logging pressure on each of the sites we also compared tree density and basal area across the three administrative categories. 


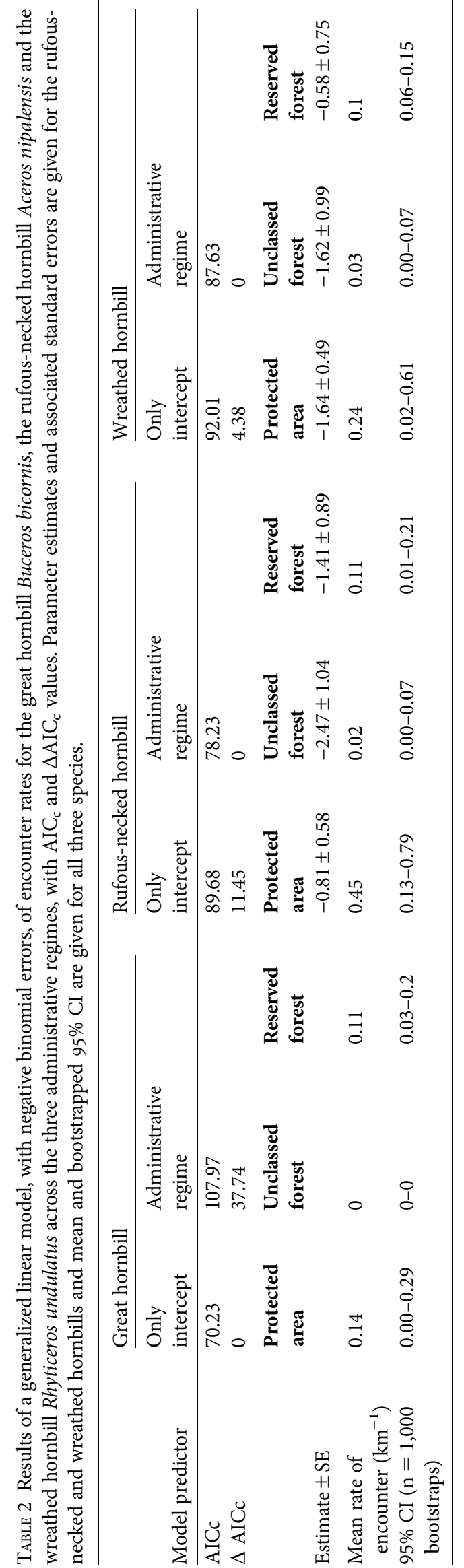

The data were non-normally distributed and therefore we compared the mean and 95\% bootstrapped $(n=1,000)$ confidence intervals for hornbill encounter rates, tree density and total basal area per hectare across protected area, reserved forest and unclassed forest. We performed all the analysis for hornbill encounter rates and vegetation data in $R$ v. 2.15.1 (R Development Core Team, 2012).

\section{Analysis of intensive survey data}

We estimated hornbill densities using DISTANCE v. 6.0 (Thomas et al., 2009). Distance sampling accounted for variability in detection probability within and outside protected areas. Distance data were grouped automatically by the software. Sightings were entered as clusters. To control influences of varying flock sizes on detectability we used size-bias regression $(\mathrm{P}=0.15)$. Standard combinations of series expansion (half-normal, uniform, hazard-rate) and key functions (cosine, simple polynomial and hermite polynomial) were used (Thomas et al., 2010). The model with the smallest AIC was chosen as the best model (Burnham \& Anderson, 2002). Given that we had only three hornbill sightings in unclassed forests over $46.3 \mathrm{~km}$ of effort we combined hornbill sightings for unclassed forests and reserved forests and compared overall hornbill densities within and outside protected areas. As the number of sightings of each hornbill species was low we estimated the detection function by pooling the detections of the three large-bodied hornbill species (2,000-3,000 g). Detections were pooled separately for inside and outside protected areas.

\section{Results}

State-wide surveys

Mean rates of encounter of hornbills (95\% bootstrapped CI) within protected areas were consistently higher than in reserved or unclassed forests for two of the three species (Table 2), for which models with administrative regime as predictor fit the data better than the basic model $\left(\Delta \mathrm{AIC}_{\mathrm{c}}>4\right)$. The mean rate of encounter with the rufous-necked hornbill in protected areas $\left(0.45 \mathrm{~km}^{-1}\right)$ was four times higher than in reserved forests $\left(0.11 \mathrm{~km}^{-1}\right)$ and 22 times higher than in unclassed forests $\left(0.02 \mathrm{~km}^{-1}\right.$; Table 2$)$. The mean rate of encounter with the wreathed hornbill in protected areas $\left(0.24 \mathrm{~km}^{-1}\right)$ was more than twice that in reserved forests $\left(0.10 \mathrm{~km}^{-1}\right)$ and eight times that in unclassed forests $\left(0.03 \mathrm{~km}^{-1}\right)$. The mean rate of encounter with the great hornbill was $0.14 \mathrm{~km}^{-1}$ in protected areas and $0.11 \mathrm{~km}^{-1}$ in reserved forests, with no encounters in unclassed forests (Table 2).

Key informant interviews indicated that in the 5 years prior to the study the great hornbill was not detected in 
TABLE 3 Summary of key informant surveys, with the number of potential sites (where each species could be present, based on their elevational and geographical ranges), the number of sites where we detected the species, the number of sites where the species was present according to the key informants but where we failed to detect it, and the number of sites where the species was not seen by key informants in the previous 5 years.

\begin{tabular}{llcll}
\hline Hornbill species & $\begin{array}{l}\text { Potential } \\
\text { sites }\end{array}$ & Detected & $\begin{array}{l}\text { Present but } \\
\text { not detected }\end{array}$ & $\begin{array}{l}\text { Not seen in } \\
\text { previous 5 years }\end{array}$ \\
\hline Great hornbill & 16 & 6 & 5 & 5 \\
Rufous-necked hornbill & 13 & 9 & 2 & 2 \\
Wreathed hornbill & 19 & 11 & 8 & 0 \\
Brown hornbill & 12 & 7 & 4 & 1 \\
$\begin{array}{l}\text { Anorrhinus austeni } \\
\text { Oriental pied hornbill } \\
\text { Anthracoceros albirostris }\end{array}$ & 14 & 3 & 9 & 2 \\
\hline
\end{tabular}

surveyed areas within two protected area sites (Mehao and Itanagar) and three unclassed forest sites (Table 3 ) and the rufous-necked hornbill was not detected at two unclassed forest sites. The only species that was reported present at all sites was the wreathed hornbill (Table 3). We considered that reports of non-detection in the previous 5 years by key informants were evidence of apparent extirpation.

Mean tree density (95\% bootstrapped CI) was lowest in reserved forests (295 trees ha ${ }^{-1}$, 95\% CI 167-421) followed by unclassed forests (504 trees $\mathrm{ha}^{-1}, 95 \%$ CI 346-641) and protected areas (525 trees ha ${ }^{-1}$, 95\% CI 379-716). Protected areas had higher mean basal area per ha $\left(60 \mathrm{~m}^{2} \mathrm{ha}^{-1}, 95 \% \mathrm{CI}\right.$ 42-80) than unclassed forests $\left(42 \mathrm{~m}^{2} \mathrm{ha}^{-1}, 95 \% \mathrm{CI}_{35}-49\right)$ and reserved forests $\left(24 \mathrm{~m}^{2} \mathrm{ha}^{-1}, 95 \% \mathrm{CI} 10-39\right)$.

\section{Intensive surveys in eastern Arunachal Pradesh}

At our intensively sampled sites we had 151 detections of five hornbill species across the three administrative regimes (Supplementary Table S1): 85 in the protected area (total effort $=189.9 \mathrm{~km}$ ) and 66 outside the protected area (total effort $=278.3 \mathrm{~km}$ ). Mean flock and individual densities of rufous-necked hornbills were more than eight times higher at the protected area site compared to outside the protected area (Table 4). Mean flock and individual densities of great and wreathed hornbills were more than twice as high in the protected area compared to outside, with overlapping 95\% confidence intervals (Table 4).

\section{Discussion}

Our state-wide survey indicates that although hornbills are present outside protected areas, mean encounter rates of the threatened rufous-necked hornbill and wreathed hornbill were lower outside than within protected areas. However, the importance of non-protected areas cannot be discounted as $>60 \%$ of the land area of Arunachal Pradesh is under forest cover, of which only $18.5 \%$ is within the protected area network (FSI, 2009). Almost $60 \%$ of the state's forested area lies in the elevation range used by hornbills (<2,000 m; Fig. 1; FSI, 2009). Thus a significant proportion of the hornbill population in the state probably occurs outside protected areas. Furthermore, individual hornbills are reported to range over areas $>170 \mathrm{~km}^{2}$ to track seasonally varying fruit resources (Kinnaird \& O'Brien, 2007; Keartumsom et al., 2011). Thus stretches of reserved forests and unclassed forests adjoining protected areas provide habitat contiguity for hornbills.

Hornbills are known to be vulnerable to hunting because of their low natural densities and slow breeding rates compared to other frugivorous birds (Bennett et al., 1997; Kinnaird \& O'Brien, 2007). Hornbill species respond variably to anthropogenic pressures such as logging: the abundance of oriental pied hornbills is higher in logged habitats, whereas great hornbills are negatively affected by logging (Datta, 1998). Our data indicate that in the two administrative regimes outside protected areas the mean rates of encounter with both the rufous-necked and the wreathed hornbill were five and three times higher in the government-regulated reserved forests than in communityregulated unclassed forests, respectively. This was despite higher tree density and basal area in unclassed forests. The lower basal area in reserved forests may be a result of historical logging pressures; other studies have shown that logging is associated with reduced basal area (White, 1994; Silva et al., 1995). The community-managed unclassed forests are probably exposed to higher hunting pressures.

Our intensive study in eastern Arunachal Pradesh also revealed that the abundance of the rufous-necked hornbill was significantly higher within the protected area (Namdapha Tiger Reserve) than outside. The densities of great and wreathed hornbill were not statistically different inside and outside protected areas. The importance of habitats lying outside protected areas is underscored by their size. The area of reserved forests in the two forest divisions (Namsai and Jairampur) in eastern Arunachal Pradesh is $1,633 \mathrm{~km}^{2}$, compared to Namdapha Tiger Reserve's $1,985 \mathrm{~km}^{2}$ (of which c. $1,200 \mathrm{~km}^{2}$ lies in the 


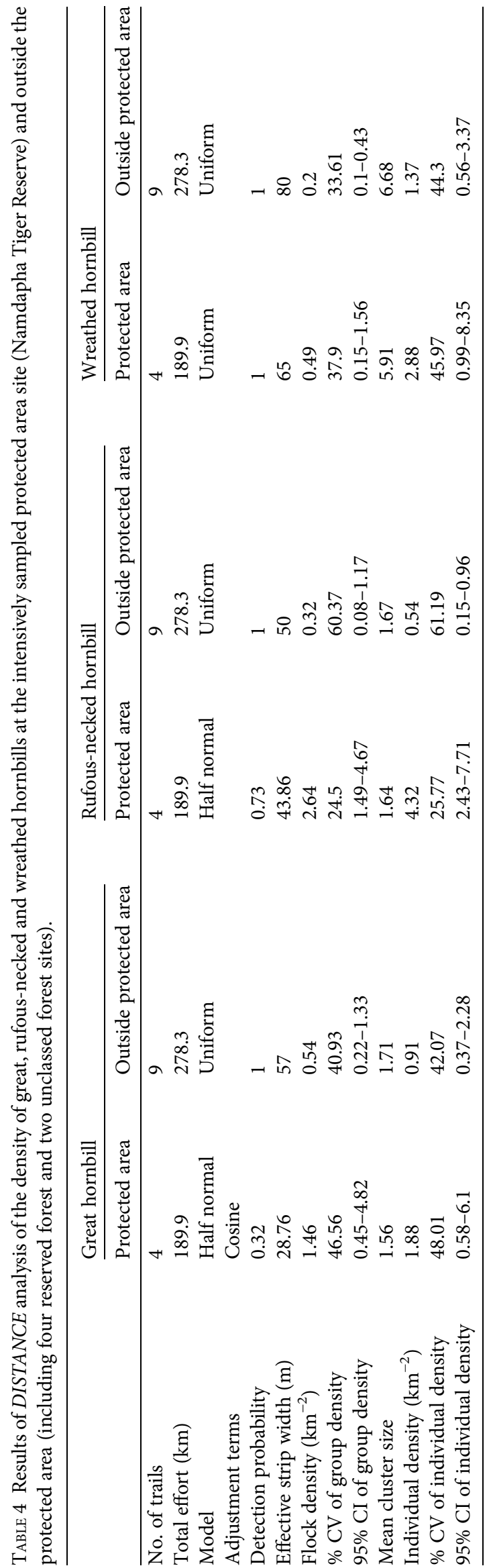

elevational range of hornbill species). The reserved forests lie entirely below 2,000 $\mathrm{m}$, which is the preferred elevation range for hornbills. Based on the estimated densities of great, rufous-necked and wreathed hornbills outside protected areas (Table 4), these two reserved forests together could harbour c. 1,500, 900 and 2,200 individuals, respectively. Similarly, reserved forests in western Arunachal Pradesh (Khellong Forest Division) with breeding populations of four hornbill species encompass larger areas $\left(>1,300 \mathrm{~km}^{2}\right)$ than nearby protected areas such as Pakke Tiger Reserve $\left(862 \mathrm{~km}^{2}\right)$. Arunachal Pradesh as a whole is therefore a globally important region for hornbills.

Given the high density (4.3 individuals per $\mathrm{km}^{2}$ ) of rufous-necked hornbills in Namdapha and the low hunting pressure on the species at this site, Namdapha Tiger Reserve appears to be a stronghold for this globally threatened species. Mean flock densities of great hornbills inside Namdapha ( 1.45 flocks per $\mathrm{km}^{2}$ ) were comparable with estimates from the Western Ghats (1.74 flocks per $\mathrm{km}^{2}$; Mudappa \& Raman, 2009). The combined densities of the three large hornbill species in the western portion of Namdapha (9.1 individuals per $\mathrm{km}^{2}$ ) were higher than the combined densities of nine hornbill species in Hala Bala Wildlife Sanctuary (5.7 individuals per $\mathrm{km}^{2}$; Gale \& Thongaree, 2006). Our key informant surveys revealed that some hornbill species are no longer detected at protected area sites where they occurred in the past. This indicates that there are significant hunting pressures on hornbills even in protected areas. At five of our surveyed sites, including two in protected areas, great hornbills are no longer reported. Body parts of the great hornbill (casque, tail feathers and body fat) are highly valued by several tribes across the state (Datta, 1998). A single casque and tail feather can be sold for up to INR 6,000 (c. USD 110) and INR 1,000 (c. USD 18), respectively (A. Datta, pers. obs.). The beaks and feathers of the rufous-necked hornbill are also used by different tribes (Datta, 2002, 2009) and the species is hunted intensively (R. Naniwadekar, unpubl. data). The rufousnecked hornbill was not detected at two unclassed forest sites, where hunting is a probable cause of its disappearance. We had limited detections of oriental pied hornbills and sampled only a few protected area sites for the brown hornbill, and therefore we are unable to draw conclusions on the status of these species across the three regimes. The presence of hornbills in forested tracts outside protected areas is a promising sign for hornbill conservation in Arunachal Pradesh. However, considering the pressures exerted by anthropogenic activities such as hunting and their potential effect on hornbill abundance, there is a need for dedicated forest management, greater conservation awareness, community involvement and incentive-based conservation practices (Datta et al., 2012) to ensure continued co-existence of humans and hornbills. 


\section{Acknowledgements}

We thank the Arunachal Pradesh Forest Department for granting us the necessary permission to carry out this research, and the officers and field staff of the Forest Department for assistance with logistics. We thank the local people for their help with fieldwork; Akhi Nathany, Rasham Barra, Narayan Mogar and Duchayeh Yobin and other field staff for their support; Jahnavi Joshi, M.O. Anand, Kulbhushan Suryawanshi and Hari Sridhar for useful discussions; R. Raghunath for preparing the map; and Dr Martin Fisher and two anonymous reviewers for their suggestions on improving this article. This study was funded by the Rufford Small Grants Foundation and Critical Ecosystem Partnership Fund with the Ashoka Trust for Research in Ecology and Environment.

\section{References}

Achard, F., Eva, H.D., Stibig, H.J., Mayaux, P., Gallego, J., Richards, T. \& Malingreau, J.P. (2002) Determination of deforestation rates of the world's humid tropical forests. Science, 297, 999-1002.

Aiyadurai, A., Singh, N.J. \& Milner-Gulland, E.J. (2010) Wildlife hunting by indigenous tribes: a case study from Arunachal Pradesh, north-east India. Oryx, 44, 564-572.

Bennett, E.L., Nyaoi, A.J. \& Sompud, J. (1997) Hornbills Buceros spp. and culture in northern Borneo: can they continue to co-exist? Biological Conservation, 82, 41-46.

Brashares, J.S., ArCese, P. \& SAm, M.K. (2001) Human demography and reserve size predict wildlife extinction in West Africa. Proceedings of the Royal Society B, 268, 2473-2478.

Buckland, S.T., Anderson, D.R., Burnham, K.P. \& Laake, J.L. (2003) Distance Sampling: Estimating Abundance of Biological Populations. Chapman and Hall, London, UK.

Burnham, K.P. \& Anderson, D.R. (2002) Model Selection and Multimodel Inference. Springer, New York, USA.

Сотtam, G. \& Curtis, J.T. (1956) The use of distance measures in phytosociological sampling. Ecology, 37, 451-460.

Curran, L.M., Trigg, S.N., McDonald, A.K., Astiani, D., Hardiono, Y.M., Siregar, P. et al. (2004) Lowland forest loss in protected areas of Indonesian Borneo. Science, 303, $1000-1003$.

DAILY, G.C. (2001) Ecological forecasts. Nature, 411, 245-245.

DatтA, A. (1998) Hornbill abundance in unlogged forest, selectively logged forest and a forest plantation in Arunachal Pradesh, India. Oryx, 32, 285-294.

D atтA, A. (2001) An ecological study of sympatric hornbills and fruiting patterns in a tropical forest in Arunachal Pradesh. $\mathrm{PhD}$ thesis. Saurashtra University, Rajkot, India.

DatтA, A. (2002) Status of Hornbills and Hunting Among Tribal Communities in Eastern Arunachal Pradesh. Unpublished report. Wildlife Conservation Society, New York, USA, and WCS-India Programme, Bangalore, India.

Datт , A. (2009) Observations on rufous-necked Aceros nipalensis and Austen's brown Anorrhinus austeni hornbills in Arunachal Pradesh: natural history, conservation status and threats. Indian Birds, 5, 108-117.

Datta, A. \& Rawat, G.S. (2004) Nest-site selection and nesting success of three hornbill species in Arunachal Pradesh, north-east
India: Buceros bicornis, Aceros undulatus and Anthracoceros albirostris. Bird Conservation International, 14, 249-262.

Datta, A., Singh, P., Athreya, R. \& Karthikeyan, S. (1998) Birds of Pakhui Wildlife Sanctuary in western Arunachal Pradesh. Newsletter for Birdwatchers, 38, 91-96.

Datta, A., Rane, A. \& Tapi, T. (2012) Shared Parenting: Hornbill Nest Adoption Program in Arunachal Pradesh. The Hindu Survey of the Environment. The Hindu, Delhi, India.

Dirzo, R. \& Raven, P.H. (2003) Global state of biodiversity and loss. Annual Review of Environment and Resources, 28, 137-167.

FSI (Forest Survey of India) (2009) State of Forest Report 2009. Ministry of Environment and Forests, Dehradun, India.

Gale, G.A. \& Thongaree, S. (2006) Density estimates of nine hornbill species in a lowland forest site in Northern Thailand. Bird Conservation International, 16, 57-69.

Gaveau, D.L.A., Wandono, H. \& Setiabudi, F. (2007) Three decades of deforestation in southwest Sumatra: have protected areas halted forest loss and logging, and promoted regrowth? Biological Conservation, 134, 495-504.

Hansen, M.C., Stehman, S.V., Potapov, P.V., Loveland, T.R., Townshend, J.R.G., DeFries, R.S. et al. (2008) Humid tropical forest clearing from 2000 to 2005 quantified by using multitemporal and multiresolution remotely sensed data. Proceedings of the National Academy of Sciences, 105, 9439-9444.

Indian Census (2011) States Census 2011. Http://www.census2011.co. in/states.php [accessed 4 November 2013].

IUCN (2011) The IUCN Red List of Threatened Species v. 2011.2. Http:// www.iucnredlist.org [accessed o8 May 2012].

Katti, M., Singh, P., Manjrekar, N., Sharma, D. \& Mukherjee, S. (1992) An ornithological survey in eastern Arunachal Pradesh, India. Forktail, 7, 75-89.

Keartumsom, Y., Chimchome, V., Poonswad, P., Pattanavibool, A. \& Pongpattananurak, N. (2011) Home range of great hornbill (Buceros bicornis Linnaeus, 1758) and wreathed hornbill (Rhyticeros undulatus (Shaw) 1881) in nonbreeding season at Khao Yai National Park, Nakhon Ratchasima Province. Journal of Wildlife in Thailand, 18, 47-55.

Kemp, A.C. (2001) Family Bucerotidae (hornbills). In Handbook of the Birds of the World (eds J. D. Hoyo, A. Elliot, J. Sargatal \& D. A. Christie), pp. 436-523. Lynx Edicions, Barcelona, Spain.

Kinnaird, M.F. \& O'Brien, T.G. (2007) The Ecology and Conservation of Asian Hornbills: Farmers of the Forest. The University of Chicago Press, Chicago, USA.

Kitamura, S. (2011) Frugivory and seed dispersal by hornbills (Bucerotidae) in tropical forests. Acta Oecologica, 37, 531-541.

Laurance, W.F., Lovejoy, T.E., Vasconcelos, H.L., Bruna, E.M., Didham, R.K., Stouffer, P.C. et al. (2002) Ecosystem decay of Amazonian forest fragments: a 22-year investigation. Conservation Biology, 16, 605-618.

Mishra, C., Madhusudan, M.D. \& Datta, A. (2006) Mammals of the high altitudes of western Arunachal Pradesh, eastern Himalaya: an assessment of threats and conservation needs. Oryx, 40, 1-7.

Mudappa, D. \& Raman, T.R.S. (2009) A conservation status survey of hornbills (Bucerotidae) in the Western Ghats, India. Indian Birds, 5, 90-102.

Naughton-Treves, L., Holland, M.B. \& Brandon, K. (2005) The role of protected areas in conserving biodiversity and sustaining local livelihoods. Annual Review of Environment and Resources, 30, 219-252.

Pimm, S.L., Jones, H.L. \& Diamond, J.M. (1988) On the risk of extinction. American Naturalist, 132, 757-785.

R Development Core Team (2012) R: A Language and Environment for Statistical Computing. R Foundation for Statistical Computing, Vienna, Austria. 
Rodrigues, A.S.L., Andelman, S.J., Bakarr, M.I., Boitani, L., Brooks, T.M., Cowling, R.M. et al. (2004) Effectiveness of the global protected area network in representing species diversity. Nature, 428, 640-643.

Sanchez-Azofeifa, G.A., Rivard, B., Calvo, J. \& Moorthy, I. (2002) Dynamics of tropical deforestation around national parks: remote sensing of forest change on the Osa Peninsula of Costa Rica. Mountain Research and Development, 22, 352-358.

Silva, J.N.M., De Carvalho, J.O.P., Lopes, J. do C.A., De Almeida, B.F., Costa, D.H.M., de Oliveira, L.C. et al. (1995) Growth and yield of a tropical rain forest in the Brazilian Amazon 13 years after logging. Forest Ecology and Management, 71, 267-274.

Thomas, L., Buckland, S.T., Rexstad, E.A., Laake, J.L., Strindberg, S., Hedley, S.L. et al. (2010) Distance software: design and analysis of distance sampling surveys for estimating population size. Journal of Applied Ecology, 47, 5-14.

Thomas, L., LaAke, J.L., Rexstad, E.A., Strindberg, S., Marques, F.F.C., Buckland, S.T., et al. (2009) Distance 6.o Release 2. Research Unit for Wildlife Population Assessment, University of St Andrews, UK.
White, L.J.T. (1994) The effects of commercial mechanized selective logging on a transect in lowland rainforest in the Lopé Reserve, Gabon. Journal of Tropical Ecology, 10, 313-322.

\section{Biographical sketches}

Rohit Naniwadekar is interested in seed dispersal, frugivory and anthropogenic effects on ecosystem processes. CHARUdutt Mishra studies carnivore ecology, large herbivore community ecology, rangelands, human ecology, and human-wildlife conflicts in snow leopard landscapes of the Himalaya and Central Asia. Kavita Isvaran is interested in the ecology and evolution of behaviour and life histories, the consequences of individual behaviour for populations, and the application of approaches from behavioural ecology and evolution to questions in conservation science. M. D. MADHUSUDAN is working to identify limits and opportunities to reconcile human resource use with the goals of conservation in India. He studies large mammal ecology in south India. Aparajita Datta's primary interests include plantanimal interactions in rainforests, understanding anthropogenic effects on wildlife, and engaging with tribal communities for conservation. 